\title{
PHARMACOGNOSTICAL AND PHYSICO-CHEMICAL EVALUATION OF KRISHNADI TAILA: A POLY HERBAL COMPOUND IN THE MANAGEMENT OF ASTIGMATISM
}

\author{
*Shah Jay Rajanikant ${ }^{1}$, Dhiman KS ${ }^{2}$ \\ ${ }^{1}$ Ph.D. (Ayu.) Scholar, Shalakya Tantra Department, I.P.G.T. \& R.A., Jamnagar, Gujarat, India \\ ${ }^{2}$ Professor and HOD, Shalakya Tantra Department, I.P.G.T. \& R.A., Jamnagar, Gujarat, India \\ *Corresponding Author's Email:drshahjay@yahoo.com, Mobile No.: 9879887175
}

\begin{abstract}
Background: The WHO has grouped Astigmatism and uncorrected refractive error among the leading causes(18\%) of blindness and vision impairment in the world. KRISHNADI TAILA (KT) is a poly herbal Ayurvedic formulation mentioned in Yogratnakara Netrarogadhikara. Though it is an important drug until date no pharmacognostical work is found on it. Objective: The present study was aimed at setting a standard pharmacognostical and pharmaceutical profile of KT. Materials and Methods: Study included preparation of KT following all SOPs using raw drugs, which were previously authenticated. Later, KT was subjected to pharmacognostical, physicochemical and high performance thin-layer chromatography (HPTLC) analysis as per standard protocols. Results: The final observations were recorded. Pharmacognostical findings matched with that of individual raw drugs with no major change in the microscopic structure of the raw drugs during preparation of Ghana Vati. HPTLC gave the fingerprint of the formulation with ten and eight spots on short and long UV, respectively. Conclusion: This shows presence of certain constituents in the powder and is helpful for the easy separation of these constituents.
\end{abstract}

Keywords: Krishnadi Taila, Astigmatism, Phyto-Constituents, HPTLC.

\section{INTRODUCTION}

The importance of vision and its organ i.e eye needs no description because for a blind person day and night are same and this world is of no use inspite he has a lot of wealth. ${ }^{1}$ In Astigmatism - a refractive error where in the patient along with the blurred vision perceives the object as distorted one, which nearly resembles the vataja type of timira. On the aetiopathological grounds refraction which differes in different meridian due to altered curvatures of refractive media i.e cornea, lens at different meridians. ${ }^{2}$ As far as the treatment of ocular diseases is concerned; it is clearly mentioned that before doing Netra Tarpana (satiating of eye with medicated / nonmedicated ghee) Shiro-Shodhana is to be carried out first. So, keeping this point in view, KT were selected for Shiro-Shodhana (Nasya). ${ }^{3}$ According to Acharya $\mathrm{Charaka}$, "A drug, that is not understood perfectly is comparable to poison, weapons, fire and the thunderbolt; while, the perfectly understood drug is comparable to ambrosia; and drug or diet article that reverses or break the Samprapti(pathogenesis) is ideal. It is often the total effect of all the ingredients in the formula rather than the action of individual drugs that plays a vital role in therapeutics. So pharmacognostical study of the contents of Krishnadi Taila was done for its identification and authentification and physio - chemical evaluation for ideality of prepared drug.

\section{MATERIALS AND METHODS}

\section{Collection, Identification and Authentication of raw drugs:}

Dried specimens of useful parts of herbal ingredients viz., Krishna, Vidanga, Madhuyashtika, Sindhujanma, Vishvaushadha and were procured from the Department of Pharmacy, IPGT\&RA, GAU, Jamnagar. Tila taila was procured from Khadi Gramodyoga Pharmacy, Jamnagar. Cow milk was procured from the local Bhavani Milk Centre, Patel Colony, Jamnagar. (Table-1) All the herbal drugs were confirmed to be authentic and of good quality by the Pharmacognosy Laboratory, IPGT \& RA, GAU, Jamnagar. The test drug KT was prepared as per classical reference and physicochemical and qualitative analysis of the final product was carried out in our laboratory of IPGT \& RA, GAU, Jamnagar.

Table 1: Ingredients of Krishnadi Taila

\begin{tabular}{|c|c|c|c|c|}
\hline Sr. No. & Drug Name & Botanical Name & Part Used & Parts \\
\hline 1 & Krishna & Piper longum Linn. & Fruit & 1 Part \\
\hline 2 & Vidang & Embelia ribes Burm. & Fruit & 1 Part \\
\hline 3 & Madhuyashtik & Glycyrrhiza glabra Linn. & Whole & 1 Part \\
\hline 4 & Sindhujanm & Rock Salt & Rhizome & 1 Part \\
\hline 5 & Vishvaushadh & Zingiber officinale Roxb. & - & 80 part \\
\hline 6 & Aja Paya & Goat milk & Sesame oil & 20 part \\
\hline 7 & Tila Taila & Sesamum indicum L. & \multicolumn{2}{|c|}{} \\
\hline
\end{tabular}


Organoleptic parameters:

Table 2: Macroscopic Features

\begin{tabular}{|c|c|c|c|c|c|}
\hline Drug Name & Part Used & Nature & Colour & Taste & Odour \\
\hline Krishna & Fruit & Fine Powder & Reddish Grey & Pungent & Characteristics \\
\hline Vidanga & Fruit & Fine Powder & Brownish & Astringent & Characteristics \\
\hline Madhuyashtika & Root & Fine Powder & Brownish & Astringent & Characteristics \\
\hline Sindhujanma & Whole & Fine Powder & Whitish Grey & Sour & Characteristics \\
\hline Vishvaushadha & Rhizome & Fine Powder & Greenish white & Bitter & Characteristics \\
\hline Aja Paya & - & Liquid & Yellowish white & $\begin{array}{c}\text { Bitter, Pungent } \\
\text { and Astringent }\end{array}$ & Pungent \\
\hline Tila Taila & Sesame oil & Liquid & Greenish black & Astringent & Charecteristics \\
\hline
\end{tabular}

Krishnadi Taila was prepared out of all the ingredients as per the Taila preparation method. Coarse Powder of all the herbal drugs was subjected for organoleptic characters which are enlisted in Table 2. The prepared test drug Krishnadi Taila (Fig 15 ) is in a liquid form, oily in touch, yellowish-black in colour with Characteristic odor and astringent in taste.

\section{Powder Microscopy:}

Powder microscopy of each raw drug was made with powder of dried samples by studying under the Carl Zeiss Microscope before and after staining with Phluroglucinol and concentrated $\mathrm{HCl}$ to study the characters of the drug (Table 3). The microphotographs were taken and attached with the microscope.

\section{[A] Krishna (Pippali):}

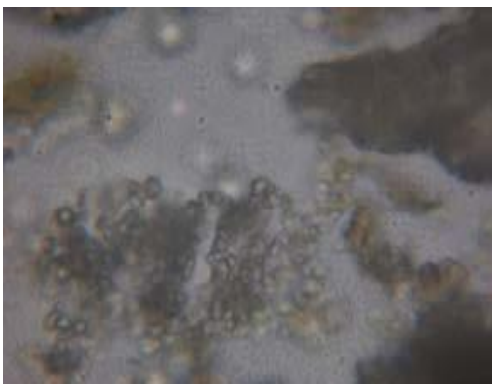

Fig 1: Starch grains without hilum

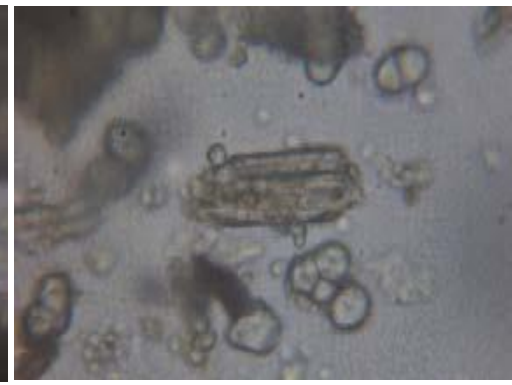

Fig 2: Stone cells

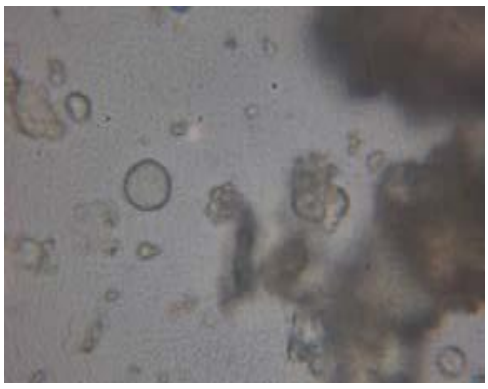

Fig 3: Oil globules

[B] Vidanga:

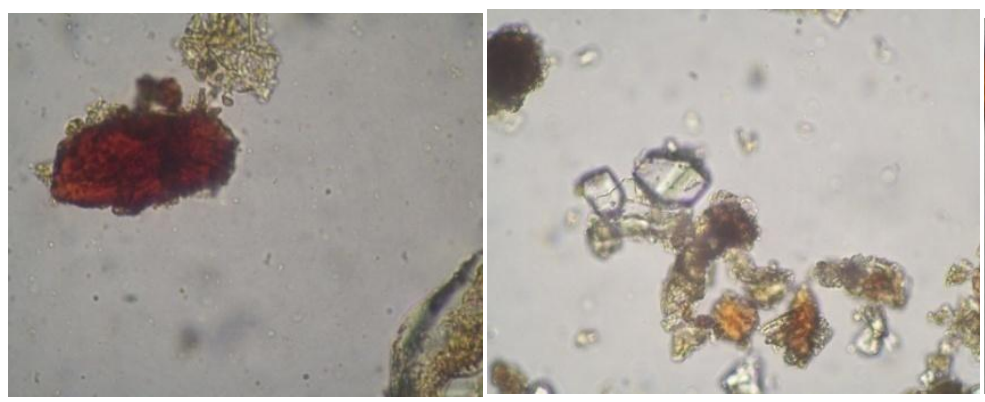

Fig 4: Fibre with wide lumen
Fig 5: Fragment of annular vessels

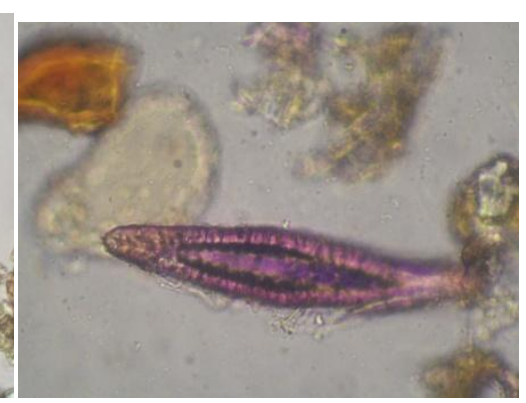

Fig 6: Pitted stone cells with wide lumen

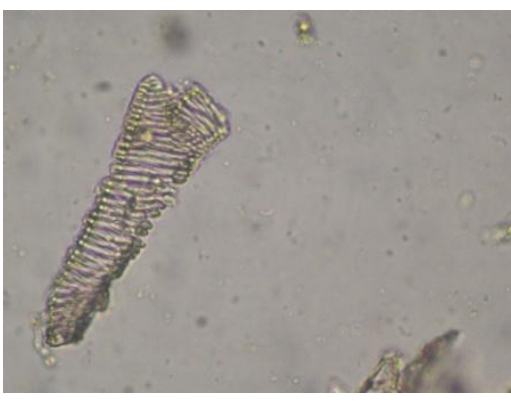

Fig 7: Rhomboid Crystles

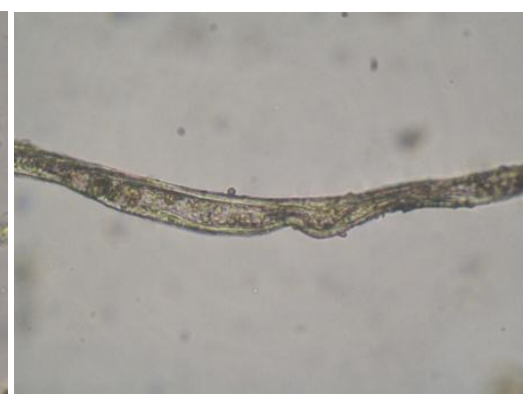

Fig 8: Tanin 
[C] Madhuyashtika:

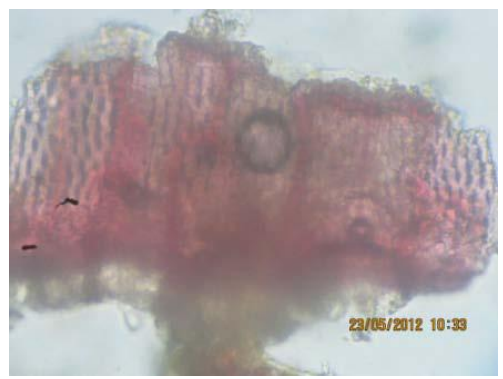

Fig 9: Pitted Vessels

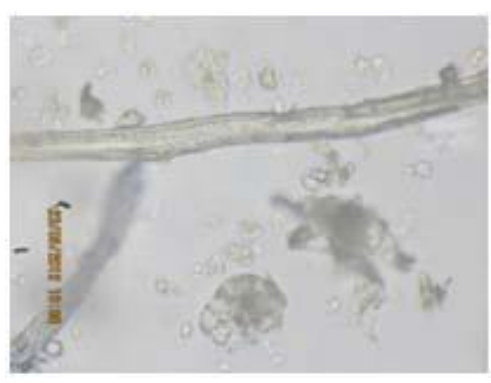

Fig 10: Simple Fibre

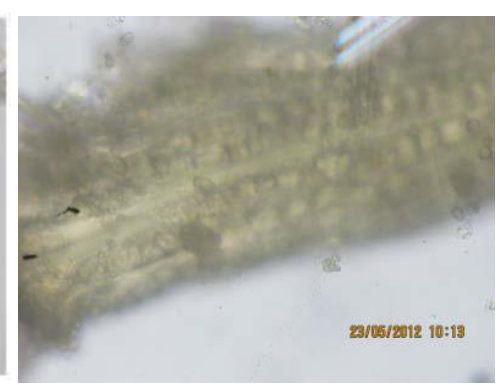

Fig 11: Crystal Fibre

[D] Vishvaushadha (Shunthi):

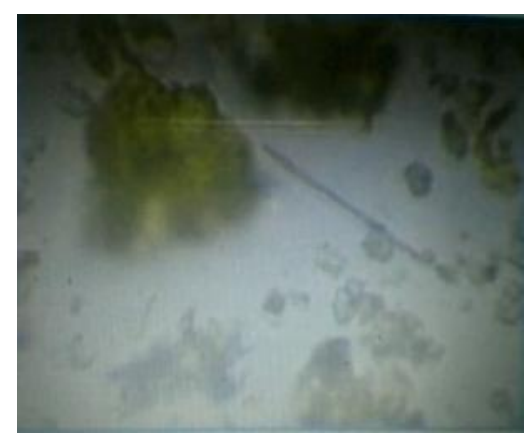

Fig 12: Oleoresin

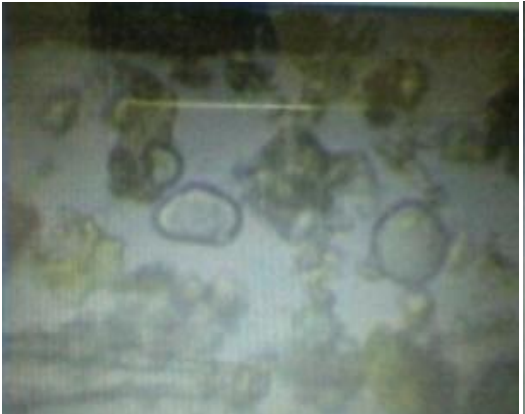

Fig 13: Simple starch grains

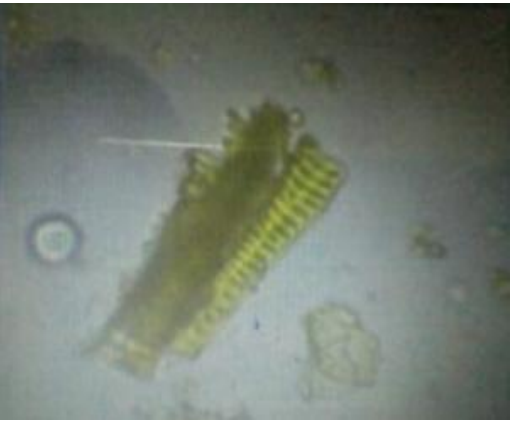

Fig 14: Annular Scalariform vessels

Table 3: Results of Powder Microscopy

(++ Seen/Present, -- Not Seen/Absent)

\begin{tabular}{|c|c|c|c|c|}
\hline Features Identified & Krishna & Vidanga & Madhuyashtika & Vishvaushadha \\
\hline Starch grains without hilum & ++ & -- & -- & -- \\
Fibre with wide lumen & -- & ++ & -- & - \\
Fragment of annular vessels & -- & ++ & -- & - \\
Rhomboid Crystles & & ++ & -- & -- \\
Tanin & -- & -- & -- & -- \\
Pitted Stone cells & ++ & ++ & -- & -- \\
Pitted Vessels & -- & -- & ++ & - \\
Simple Fibre & -- & -- & ++ & +- \\
Crystal Fibre & -- & -- & ++ & +- \\
Oleoresin & -- & -- & -- & ++ \\
Simple starch grain & -- & -- & -- & -- \\
Annular Scalariform vessels & -- & -- & -- & \\
Oil globules & ++ & -- & & \\
\hline
\end{tabular}

\section{Preparation of the Drug:}

\section{Preparation of Coarse Powder:}

The herbal drugs enlisted from 1 to 5 (Table 1) were washed, dried and a stipulated quantity made into coarse powder and divided into two parts. Out of this major part $\left(3 / 4^{\text {th }}\right)$ was used for $k$ watha preparation and smaller portion $\left(1 / 4^{\text {th }}\right)$ used for preparing Kalka.

\section{Preparation of Kwatha (Decoction):}

Decoction was prepared based on Sharangadhara Samhitas general rule by mixing above said coarse powder of the drugs with water in the ratio of $1: 8$, which was there after heated at medium temperature, till it reduced to one fourth of its original quantity and filtered multiple fold thoroughly to avoid fine particles in the final filterate (decoction).

\section{Preparation of Kalka (Paste):}

The second part of the raw drug was taken and mixed with required quantity of water to convert into paste form.

Taila Paka Vidhi: This was carried out as per the method prescribed in the classics ${ }^{4}$. Initially Tila Taila kept in iron vessel was subjected for Moorchana. After completion of moorchana, temperature raised to $70^{\circ} \mathrm{C}$. At this moment Kalka was added with continues stirring. To this decoction, cow milk was added with continues stirring. After proper mixing of 
all the ingredients, temperature was maintained between $65^{\circ} \mathrm{C}$ to $100^{\circ} \mathrm{C}$, heating was carried out for two days, on second day after attaining Madhyama Paka Taila sidda lakshanas, final product of Krishnadi Taila was collected, filtered thoroughly and stored in a iron vessel for one month before subjecting for usage.

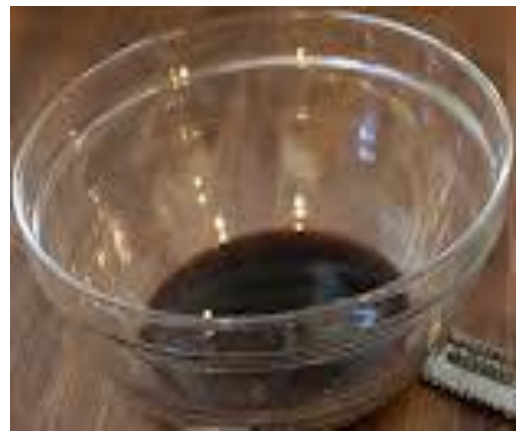

Fig 15: Krishnadi Taila

\section{Physicochemical Parameters and Qualitative Analysis:}

Krishnadi Taila was analyzed by using qualitative and quantitative parameters at Pharmaceutical Chemistry Laboratory, IPGT\&RA, GAU, Jamnagar. All Physico-chemical parameters such as Acid value, Iodine Value, Saponification Value, Refractive Index and specific Gravit ywere determined. (Table 4)

Table 4: Physico-Chemical Parameters Of Krishnadi Taila

\begin{tabular}{|c|c|c|}
\hline Sr. No. & Analytical parameters & Results \\
\hline 1 & Acid value & 2.2645 \\
2 & Iodine value & $80.70 \%$ \\
3 & Saponification value & 144.57 \\
4 & R.I. & 1.489 \\
5 & Specific gravity & 0.9677 \\
\hline
\end{tabular}

(R. I.: Refractive Index)

The water and methanol extract of the sample was analyzed qualitatively for different functional groups. In qualitative method, presence of flavonoids, Phytosterons, Isoflavones tannins, saponin, alkaloids, glycosides and carbohydrates were assessed (Table 5). ${ }^{5}$

Table 5: Qualitative Analysis of Krishnadi Taila

\begin{tabular}{|l|l|}
\hline Functional Group & Sample \\
\hline Flavonoids & Positive \\
Tannins & Positive \\
Alkaloids & Positive \\
Saponin & Positive \\
Carbohydrates & Positive \\
Glycosides & Positive \\
\hline
\end{tabular}

TLC and HPTLC were carried out after preparing an appropriate solvent system with methanolic extract of Krishnadi Taila. $^{6}$

HPTLC were performed for the normal phase separation of components of methanol extracts of $K T$. HPTLC study of the methanol extract was also carried out by using the solvent system of Hexane : Diethyl ether : Acetic Acid $6.5: 2.5: 1.0$ ratios. After completion of HPTLC; post chromatographic derivatization was done with vanilline sulphuric acid. ${ }^{7}$

\section{RESULT \& DISCUSSION}

\section{RESULTS}

The initial purpose of the study was to confirm the authenticity of the drugs used in the preparation of KT. For that, detailed organoleptic evaluation was carried out for the course powder of all the herbal ingredients of KT.

The powder microscopy of the Pippali revealed presence of Starch grains without helium, Stone cells, Oil globules. (Fig 13) Vidanga showed Fragment of Fibre with wide lumen, Fragment of annular vessels, Pitted stone cells with wide lumen, Rhomboid Crystles and Tanin. (Fig 4-8) Madhuyashtika showed Pitted Vessels, Simple Fibre, Crystal Fibre. (Fig 9-11) 
Shunthi showed Oleoresin, Simple starch grains, Annular Scalariform vessels. (Fig 12-14) The diagnostic features obtained by powder microscopy were compared with the standards mentioned in Ayurvedic Pharmacopeia of India (API). The details of Pharmacognostical study are enlisted in the Table 3. ${ }^{8}$

\section{Physicochemical parameters and Qualitative Test:}

Qualitative tests indicated presence of alkaloids, tannins, glycosides, saponin, flavonoids, protein, carbohydrates and steroid. Details are shown in the Table 5.

\section{DISCUSSION}

Pharmacognosy study helps in authentication of commonly used drugs through morphological, histological and Physicochemical parameters. This can prevent the accidental misuse of drugs and adulteration to a greater extent. In the present study the formulation consist of five herbal ingredients which were proved to be genuine by assessing the Pharmacognostical parameters. The presence of flavonoids, tannins, alkaloids, saponin, isoflavones, carbohydrates and glycosides etc., are the commonest features seen in all the ingredients.

Evaluation of Physico-chemical parameters and qualitative analysis helps to assess the quality and identify the presence of specific ingredients in a formulation and application of chromatographic techniques which aid in recognition of number of ingredients and also to assess the purity by comparing with the standard ones. Refractive Index Value 1.489, Specific Gravity

Table 6: Results of Hptlc of Krishnadi Taila

\begin{tabular}{|c|c|c|c|c|}
\hline Extract & Solvent system & Wavelengths & Spots & Rf value \\
\hline \multirow[t]{2}{*}{ Methanol } & \multirow{2}{*}{$\begin{array}{l}\text { Hexane : Diethyl ether : Acetic } \\
\text { Acid }(6.5: 2.5: 1.0)\end{array}$} & $254 \mathrm{~nm}$ & 10 & $\begin{array}{l}0.01,0.13, \\
0.20,0.33, \\
0.39,0.47, \\
0.56,0.64, \\
0.81,0.89\end{array}$ \\
\hline & & $366 \mathrm{~nm}$ & 08 & $\begin{array}{c}0.01,0.27, \\
0.33,0.38, \\
0.73,0.81, \\
0.88,0.94\end{array}$ \\
\hline
\end{tabular}

0.9677, Acid Value 2.2645, Saponification Value 144.57, Iodine Value $80.70 \%$, all the parameters were within the standard limit. HPTLC is the most common form of chromatographic method used by Ayurvedic research workers to detect the number of compounds present in a product. It also helps to determine the purity of the sample. Identification of a compound is also possible by comparing it with the $\mathrm{Rf}$ value of a known compound. Here for the purpose of conducting HPTLC of KT tracks was made having the sample methanol extract. After careful analysis and discussion with experts the mobile phase was fixed to be Hexane : Diethyl ether : Acetic Acid $6.5: 2.5: 1.0$ in ratio V/V. The sample tracks and mobile phase remained the same for all the experiments related to HPTLC. The spots produced by HPTLC were observed in short $\mathrm{UV}(254 \mathrm{~nm})$ and long $\mathrm{UV}(366 \mathrm{~nm})$ and Rf value was calculated.Track showed 10 spots under $254 \mathrm{~nm}$ with Rf 0.01 , $0.13,0.20, \quad 0.33,0.39, \quad 0.47,0.56, \quad 0.64,0.81, \quad 0.89$ and 08 spots were seen under 366 nm with Rf 0.01,0.27,0.33,0.38,0.73,0.81,0.88,0.94 values. Details are noted in the Table 6 and Fig 16 and 17.

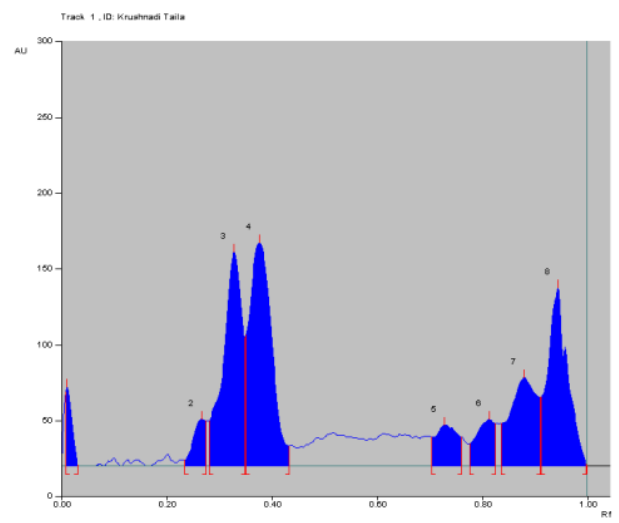

Fig 16: Densitogram of Methanol Extract of KT at $254 \mathrm{~nm}$

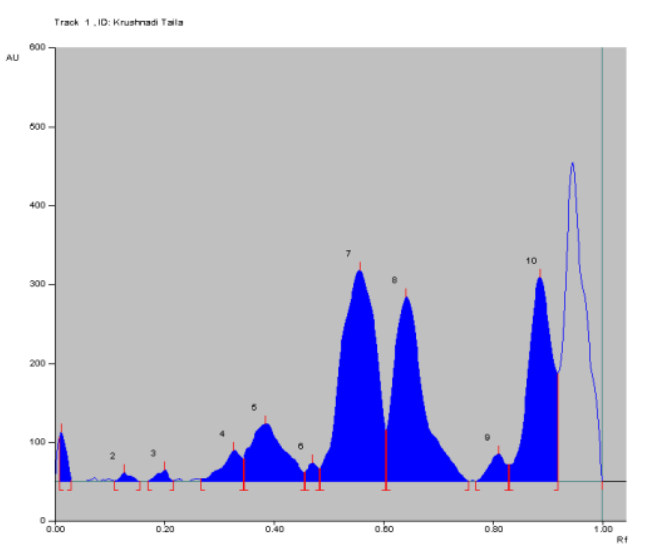

Fig 17: Densitogram of Methanol Extract of KT at $366 \mathrm{~nm}$

The results shows that the active phytoconstituents are more sensitive for short UV radiation that is $254 \mathrm{~nm}$ when compared with $366 \mathrm{~nm}$ UV wavelength. 


\section{CONCLUSION}

Preliminary Organoleptic features and results of powder microscopy were compared with the parameters mentioned in API and all the ingredients were proved to be authentic. In Phytochemical analysis RI, Acid Value, Saponification value, Iodine Value and Specific Gravity were assessed and all the values were in the normal range as per the standard values mentioned in API. Qualitative analysis revealed the presence of Tannins, Saponins, alkaloids, Glycosides, Carbohydrates and Flavonoids in the Taila. Though the base work requisites for the standardization of $K T$ are covered in the current study, however additional analysis and investigations are required for the identification of all the active chemical constituents of the test drug to substantiate the clinical efficacy.

\section{FINANCIAL AID}

I.P.G.T. \& R.A., Gujarat Ayurved University, Jamnagar

\section{CONFLICTS OF INTEREST}

No any personal or financial relationships that could be viewed as potential conflicts of interest in relation to the publication.

\section{REFERANCES}

1. Yadunandan U. Ashtanga Hridaya with Vidyotini Hindi Teeka. Varanasi: Chaukhamba Sanskrit Sansthana; 1980.

2. Khurana AK. Comprehensive ophthalmology. $4^{\text {th }}$ ed. New Delhi: New Age International (P) Limited Publishers 2007;03:33-34.

3. Laxmipati S., Yogaratnakara Hindi commentary. $3^{\text {rd }}$ ed. Varanasi: Chaukhamba Sanskrit Sansthana; 1983.

4. Vagbhata. Astanga Hrdayam - with commentaries (sarvanga sundara) of Arunadatts and (Ayurnveda rasayana) of Hemadri, Uttaratantra,

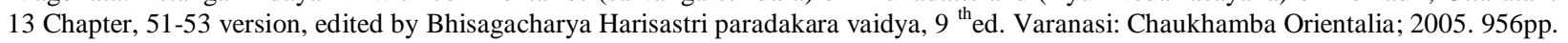

5. Pharmacological Investigations of certain medicinal plants \& compounds formulations used in Ayurveda and Siddha., CCRAS Minis try Of Health \& FW GOI, New Delhi, First Edition.

6. Stahl E; Thin-layer chromatography. 2nd Ed. Springer-Verlag New York, Inc. 175 5th Ave. New York, NY.1969; pp 125 -133.

7. Reich E, Schibii A; High Performance- Thin Layer Chromatography for the analysis of medicinal plants. Germany: Thieme medical publishers. Inc. 2007. p. 129-60, 206-10, 224-40.

8. Anonymous, Atlas of Macrscopic \& Microscopic characters of Ayurvedic Pharmacopial Drugs, The Ayurvedic Pharmacopoeia of India, Part II, Volume I, First Edition, Government of India, Ministry of Health and Family Welfare, Department of A YUSH, New Delhi, 2007 p6-8, 75, 80,90. 